\title{
邦人下顎第一大自齔，齔根站二 根管二就イテ
}

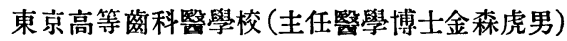

堀

Über die Wurzeln und Wurzelkanäle des unteren Molaren des Japaners. Von Dr. Takeshi Hori.

$\begin{array}{lll} & \text { 目 次 } \\ \text { 緒 論 } & \text { 調查成績 } \\ \text { 観察方法 } & \text { 結 論 }\end{array}$

\section{緒論}

吾人ガ日常遭遇スル治療時, 難事ハ, 如何二根管 キ處置シ, 齒牙チ保存ス可キカニ 在ル。而シテ其成否八兩極端二相離ルルモノニシテ, 咀嚼, 咬斷ノ用二堪へテ, 全キ

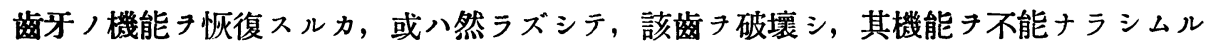

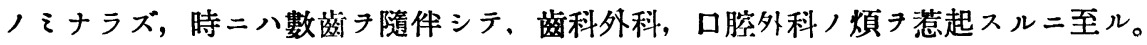

即齒牙保存ノ生命八完全ナル根管ノ處置ニアリ。而シテ如何ニシテ根管き處置シ, 齒牙, 保存丹計ル可キカ八臨牀家, 最モ腐心スル問題ニシテ, 此ノ問題キ解決スルニ 緊要ナル條件ハ, 崡根ノ解剖學的形態及ビ根管ノ構造二關スル正確ニシテ且ツ精密ナ ル基礎的智識き探究スルニアリ。

從來根管八比較的單純ニシテ,簡單二處理サルルモノト思惟サレシモ, 1901 年“Die Pulpa amputation”ト題スル Preiswerk 氏ノ研究論文發表七ラレテ以來, 諸學者間 二種々論究セラレ, 幾多, 業績きミルト共ニ, 根管八複雜, 精巧ナル構造ヨ有スルモ ノトナレリ。之ニ反シテ齒根, 研究ハ根管二比シテ, 今俘等閑二付セラレタル觀アリ。

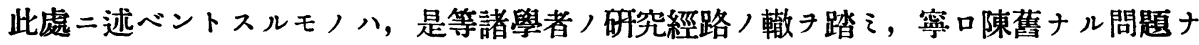

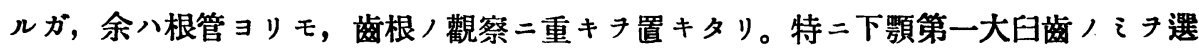
ビテ攻究シタル所以ハ, 全齒中最モ重要ナル齒牙ナル事及ビ當附屬病院二於テ屢 $、$ 四 根管二遭遇スル事二動機き發セルモノナリ。 


\section{睍察方法}

(1) 本邦人下顠第一大白齒 735 齒

（2）測定器。Calipars, 彈力性二富么針金, Kerr ノ Broach Reamers, 及ビ A

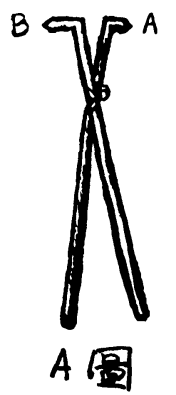
圖ノ如キ手製ノモ, チ使用シタリ。

[註] $\mathrm{A}$ 圖ノ器具ハ齒根間ノ直弳尹測定スルニ用ヒタルモノナ リ。齒根裂溝八, 齒根, 中央部于近遠心的二陷凹シテ, 根分岐部ヨ

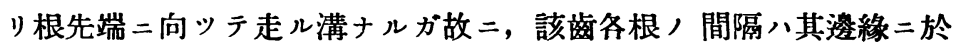
テ狹ク, 中央部 至ルニ從ヒ廣クナルキ以ッテ Calipars ソノ他ノ 器具ニテハ精傕ナル 測定キナシ得ズ。郎チ圖ノ如ク， 2 個ノ强固ナ ル針金ヲ交刃シ，其先端キ屈曲シテ相反セシメタルモノナリ。測定 時二ハ 2 線尹合シテ橫入シ, 測定部位二達シタル時, 縱二起シテ兩 線キ開キ, $a, b$, 部キ兩根二接觸セシメ, 指頭二テ固定シタル後, 插入時ト同樣ニシ テ取リ出シ, $a, b$, 間ノ間隔キ Calipars チ以ッテ測定スルモノナリ。

（3）觀察方法。以上ノ諸器具 キ用七テ, 齒根諸部分ノ徑數丹測定シテ, 其本均徑

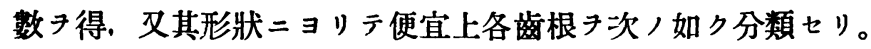
(1) 圓錐型齒根。
(2) 方型齒根。
(3) 圓頭型齒根。
（4）刀型齒根。
（5） 分離三根型齒根。

根管二就イテノ研究方法ハ從來種々アリテ,ソノ大要キ述ブレバ次ノ如シ。

（1）根管內ハ不透視性ノ材料キ注入充填シ，齒牙き透明トナシ，以ッテ根管キ檢 ス。墨汁 (Moral 氏, 小野氏)。朱, 蜜䗒, (Grove 氏兩者併用)。

（2）金屬, 其他「七ルロイド」樣物質きシテ, 根管內容二代ラシメ, 齒牙ョ破壞シ テ外部ニ取リ出シテ檢ス。Wood Metal (Preiswerk 氏),「七ルロイド」(Fischer 氏), 蒸和護謨 (Hess 氏)。

(3) X光線不透過性ノ材料き滿シ, X光線像ニョリテ檢查ス。

(4) Schliff Präparat キ作鄨シ，根管き露出シテ檢ス。

（5）脫灰後 Zelloidin二包埋シテ, 連續切片チ作リ, 顯鏡シテ檢ス。

以上ノ何レカノ方法二從ヒテ、觀察スルモノナリ。次二諸學者, 研究法丹簡單二擧 グレバ.

（1）Preiswerk 氏全屬注入法。1901 年。

（2） Fischer 氏「セルロイド浸潤法。1908 年。 
（3）Adloff 氏「ウッドメタル」注入法。1913 年。

（4）Moral 氏墨汁法。1914 年。

其他 Grove, Port, Hess, Zurcher，八木，小野，奧村諸氏ノ種々ナル研究アリテ, 其業績ハ枚擧ス可カラズ。余ハ次ノ如キ三ッノ方法キ行ヒタリ。節

唀明標本製作法。

（1）拔齒後 $10 \%$ Formalin 中二固定セル齒牙チ取リ出シテ, 第 $1=24$ 時間水洗 シタル後, 髓腔き開放シ, 約 6 時間 Antiformin 二投ジテ, 齒牙キ漂白スルト同時 二附著七ル軟組織及ビ齒石, 齒垢き溶解除去ス。然ル後再ビ 24 時間水洗シテ, Antiformin チ去リ、齒牙チ精細二檢査シテ, 損傷龜裂ナキモノノ゙タ選ブ。次二布片キ

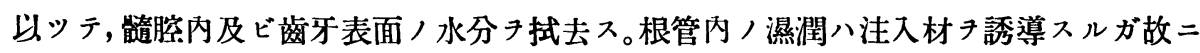
脫水ハ行ハズ。ツイデ左手ノ布片ニテ把持シ乍ラ, 墨汁或ハ朱 髓腔 $1 / 3$ / 部分ニマデ 注入ス。茲二於テ一方二蒸和護謨ノ小片チ「ブンゼン」燈上二溫メ置キ, 髓檫ノ注入終 リタラバ, 此小片チ指頭二テ, 適宜二丸メ 髓膑ヨリ少シク大ナラシメテ注入夜,上 部二靜置ス。墨计，朱ノ注入多量ナル時或八護謨片ノ髓腔卜等シキカ,小ナル場合ハ, 厭迫時, 注入液外表へ逸出シテ齒牙チ污損スル懼レアリ。故ニ根管口ト思シキ部分二 硝子棒或ハ注射器 キ以ツテ該夜丹滴下シ, 漸次追加シテ $1 / 3$ 二達セシムルチ可トス。 小量ナル場合八根管內深部二到達不可能ナリ。

護謨片チ安置シタラバ, 齒牙チ把持シ乍ラ, 木製 Nadel / 柄ノ先端ニテ. 徐々二加 压シ根管內二厣入ス。然ル時ハ根端孔ョリ注入液壓出シ來ルチ以ッテ, 布片二テ拭キ 取リ, 此ノ方法キ 2,3 包繰返セバ, 微細ナル側枝ノ部分ニマデ滿シ得ルニ至ル。

以上ノ操作キ終リタラバ, 數時間氣中二放置シテ, 内容液き乾涸セシム。脫灰液及 ビ脫灰法八小野氏法二從七, 注入液乾燥後, 次, 如キ處方, 脫灰液二投

$\begin{array}{lr}\text { 日局硝酸 } & 15.0 \\ \text { 酒 精 } & 10.0 \\ \text { 水 } & 100.0\end{array}$

脫灰液ハ 3 日オキ二新鮮ナルモノト交換シ, 1 日數包振䠄スレバ10日乃至 2 週間二 シテ完全二脫灰ス。脫灰完了シタラバ, 重曹水二テ中和シ, 再ビ流水二テ 24 時間水洗 ス。然ル後 $70 \%, 90 \%$, 純「アルコホール」二順次二投入、最後二「アセトン，アルコ ホール」中ニ入レテ完全二脫水テ行フ。透明標本製作,完否ハ完全ナル齒質,脫灰卜 脫水トニアリ。不完全ナル場合ハ溷濁シテ透視不可能ニシテ目的き達シ得ズ。是等， 諸操作ヨ順次ニ終リタラバ, 最後ニ市販ノ冬綠油中二投ジ透明トナス。從來使用サレ 
タル透明液ハ，流動石炭酸 (Moral 氏)，「グリセリン」(Grove 氏)，「チェデル」油 (Adloff 氏)，「ベンゾール, ベンゾっート」(小野氏)，「ピリヂン」(菅沼氏)，冬綠油(小 野氏）等ナリ。・冬綠油二投ズレバ 30 分ニシテ透明トナリ，根管及ビ側枝キ完全二明 視シ得ルニ至ル。而シテ同液中二保存ス。

（2）墨汁，朱／厭入時期子牛脫灰後二行七, 再ビ脫灰、透明ニナス。

（3）脫灰, 透明二シタル後, 徐々二注入液子壓入入。此,方法八石灰分消失面人 注入液ノ逸入スル懼レアリ，且ツ注入液不乾涸ノ缺點アルモ，壓迫卜同時二, 漸次根 管深部, 側枝部へ進入シ行ク狀態テ目視シ得ルノ便アリ。

以上ノ三法ニ依リ 444 齒キ透明ニシテ，根管及ビ側枝ノ狀態き觀察セリ。

\section{調査成績}

\section{A 需 根}

通常近遠心，兩側二各了 1 個テ有スルモノナルガ, 時二八遠心根, 頓舌的 $=2$ 根 トナリ， 3 根齒き 形成スル事アリ。近遠心 2 根ハ相接近シテ立行スルモ離開大ナラ ズ。葘頸部ヨリ分岐シ, 近溒心的二壓本サレテ扁本トナリ, 其ノ各?/近遠心面二於 テハ縱溝明カナリ。全長，牛ョリ漸次遠心ニ矮曲スルモ, 稀ニハ兩根直立スル事ア リ。先端ハ一般二銳利ニシテ，其頓舌的兩面八圓澤ナリ。形狀八圓錐型キナスモ，最 モ多キモ又圓頭型, 方型, 刀型モ亦少シトセズ。

近心根。近心根八, 遠心根二比シ稍 3 大ニシテ頓舌的二廣ク, 其筧曲度モ著シ。埾 本度甚シクシテ, 扁平トナリ, 縱溝著明ニシモ, 宛モ 2 根二分離七ントスルモノモア リ。

遠心根, 近心根二比シ稍 3 短小ニシテ, 篦曲度モ少ク, 扁本ナルモノ多キモ, 稀二 八近遠心面豐隆シテ，棒狀キナスモノモアリ。斯如キモノ八縱溝キ認メズ。近心根卜 最モ相違スル點八，屢了 2 根二分岐スル事ナリ。其分離 2 根八共二甚シク 小ナリ。殊

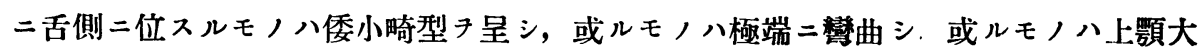
白苳口蓋根ノ如ク大イ二嚁開ス。

調查成績。

(1) 齒根數, (735 齒)。

2 根蓄 600 齒。 $81.6 \%$

3 根齒 135 齒。18.4\%

(2) 齒根徑數。(1605 齒)。 
(a) 各齒根/長徑。

2 根齒ノ近心根本均脣徑。12.2m.m.

" " 遠心根 " " " $11.1 \mathrm{~m} . \mathrm{m}$.

分離 3 根齒, 近心根長徑。 $14.1 \mathrm{~m} . \mathrm{m}$.

" " 遠心煩側根 " 。 $12.5 \mathrm{~m} . \mathrm{m}$.

, " 遠心舌側根 , 。11.2m.m.

(A)

\begin{tabular}{|c|c|c|}
\hline \multicolumn{3}{|c|}{ 齒根數 (735) 商 } \\
\hline 二根齒 & 600 & $81.6 \%$ \\
\hline 三根薁 & 135 & $18.4 \%$ \\
\hline
\end{tabular}

(B)

\begin{tabular}{|c|c|c|c|c|c|c|}
\hline \multicolumn{7}{|c|}{ (1605图) } \\
\hline 商牙 & 各 齒 根 & 本 & 均 & 最 & 長 & 最 ${ }^{-}$短 \\
\hline \multirow{2}{*}{$\begin{array}{l}\text { 示 } \\
\text { 根 } \\
\text { 离 }\end{array}$} & 近 心 根 & \multicolumn{2}{|c|}{$12.2 \mathrm{~mm}$} & \multicolumn{2}{|c|}{$18.8 \mathrm{~mm}$} & $5.9 \mathrm{~mm}$ \\
\hline & 遠 心 根 & \multicolumn{2}{|c|}{11.1,} & \multicolumn{2}{|c|}{16.5,} & 5.8, \\
\hline \multirow{3}{*}{$\begin{array}{l}\text { 三 } \\
\text { 根 } \\
\text { 瞄 }\end{array}$} & 近 心 根 & \multicolumn{2}{|c|}{14.1,} & \multicolumn{2}{|c|}{16.5.} & 12.0, \\
\hline & 遠心煩側根 & \multicolumn{2}{|c|}{12.5,} & \multicolumn{2}{|c|}{14.8,} & 10.6, \\
\hline & 遠心舌側根 & \multicolumn{2}{|c|}{11.2,} & \multicolumn{2}{|c|}{13.3,} & 8.3, \\
\hline
\end{tabular}

(b) 各齒根) 横徑。

1 齒根ノ頓舌的ノ直徑キ測定シタルモノニシテ, 齒頸部, 中央部及ビ方型齒根, 先 端部ノ 3 部ノ本均徑數キ測ル。

(1) 齒頸部。

\begin{tabular}{|c|c|}
\hline 2 根齒ノ近心根 & $8.8 \mathrm{~m} . \mathrm{m}$. \\
\hline " $\quad$ 遠 & 8.3m.m. \\
\hline 3 根齒ノ 迟 & $9.2 \mathrm{~m} . \mathrm{m}$ \\
\hline 遠心炏 & $6.6 \mathrm{~m} . \mathrm{m}$ \\
\hline 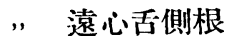 & $3.9 \mathrm{~m} . \mathrm{m}$ \\
\hline
\end{tabular}

(2) 中央部。

\begin{tabular}{|c|c|}
\hline 2 根齒ノ近心根 & $7.6 \mathrm{~m} . \mathrm{m}$. \\
\hline 遠心根 & $7.1 \mathrm{~m} . \mathrm{m}$. \\
\hline 3 根齒ノ近心根 & $7.9 \mathrm{~m} . \mathrm{m}$ \\
\hline " 遠心煩側根 & $5.7 \mathrm{~m} . \mathrm{r}$ \\
\hline 遠心 & $3.4 \mathrm{~m}$ \\
\hline
\end{tabular}

(3) 先端部。

方型根齒八 2 根齒ノ近遠心兩根及ビ 3 根齒ノ近心根二在リ。 
(C)

\begin{tabular}{|c|c|c|c|c|c|}
\hline \multicolumn{6}{|c|}{ 图 根 橫 徑 (1605蒛根) } \\
\hline \multicolumn{2}{|c|}{ 部位漓牙 } & 各菌根 & 本 均 & 最 長 & 最 短 \\
\hline \multirow{4}{*}{$\begin{array}{l}\text { 㡙 } \\
\text { 頸 }\end{array}$} & \multirow{2}{*}{$\begin{array}{l}\text { 示 } \\
\text { 根 } \\
\text { 离 }\end{array}$} & 近心根 & $8.8 \mathrm{~mm}$ & $10.6 \mathrm{~mm}$ & $6.9 \mathrm{~mm}$ \\
\hline & & 遠心根 & 8.3, & 11.5, & 4.8, \\
\hline & 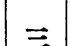 & 近心根 & 9.2, & 10.7, & 8.2. \\
\hline & 根 & $\begin{array}{l}\text { 遠心煩 } \\
\text { 側根 }\end{array}$ & 6.6, & 8.2, & 5.3, \\
\hline 品 & 离 & $\begin{array}{l}\text { 這心舌 } \\
\text { 側根 }\end{array}$ & 3.9, & 6.7, & 2.9, \\
\hline \multirow{2}{*}{ 中 } & \multirow{2}{*}{$\begin{array}{l}\text { 眼 } \\
\text { 㡙 }\end{array}$} & 近心根 & 7.6, & 9.4, & 5.3, \\
\hline & & 遠心根 & 7.1, & 10.9, & 3.9, \\
\hline 央 & \multirow{3}{*}{$\begin{array}{c}\text { 三 } \\
\text { 根 } \\
\text { 齒 }\end{array}$} & 近心根 & 7.9, & 9.0 & 6.3, \\
\hline 部 & & $\begin{array}{l}\text { 遠心煩 } \\
\text { 則根 }\end{array}$ & 5.7, & 7.2, & 4.4, \\
\hline & & $\begin{array}{l}\text { 遠心舌 } \\
\text { 側根 } \\
\end{array}$ & 3.4, & 4.0, & 2.6, \\
\hline \multirow{3}{*}{$\begin{array}{l}\text { 先 } \\
\text { 端 } \\
\text { 部 }\end{array}$} & \multirow{2}{*}{$\begin{array}{l}\text { 要 } \\
\text { 㮰 }\end{array}$} & 近心根 & 4.3, & 8.5, & 2.5, \\
\hline & & 遠心根 & 3.6, & 8.3, & 2.4, \\
\hline & $\mid$ & 近心根 & 4.5, & 6.6, & 4.6, \\
\hline
\end{tabular}

(D)

\begin{tabular}{|c|c|c|c|c|c|}
\hline & & 苜 & 。 間 & 徑 & \\
\hline 部位 & 苜牙 & 樆 根 間 & 平 均 & 最 長 & 最 短 \\
\hline & 根 $^{\text {苜 }}$ & 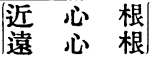 & $3.4 \mathrm{~mm}$ & $7.5 \mathrm{~mm}$ & $0.2 \mathrm{~mm}$ \\
\hline 光 & & $\mid \begin{array}{|cc|}\mid & \text { 心 } \\
\text { 遠心根 }\end{array}$ & 4.7, & 9.5, & 1.8, \\
\hline 端 & & 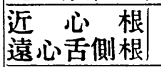 & $5.1 "$ & 7.8, & 2.7, \\
\hline 部 & & 遠心煩側根| & 7.2, & 11.0, & 3.9, \\
\hline 中 & 根 & 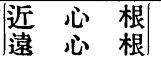 & 2.7, & 4.9 , & 0.6, \\
\hline 央 & & 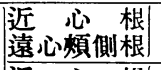 & 2.1, & 3.6, & 0.5, \\
\hline & & 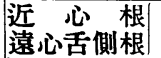 & 1.8, & 4.0, & $0.4 .$, \\
\hline 마 & & $\mid$\begin{tabular}{|l} 
遠心煩側根 \\
禁心側根
\end{tabular} & 2.9, & 4.4, & 1.4, \\
\hline 炃部 & 根 & 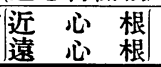 & 0.4. & 2.9, & 0.3, \\
\hline
\end{tabular}

2 根齒ノ近心根 $\quad 4.3 \mathrm{~m} . \mathrm{m}$.

" 遠心根 $\quad 3.6 \mathrm{~m} . \mathrm{m}$.

3 根茼/近心根 $\quad 4.5 \mathrm{~m} . \mathrm{m}$.

（c）各齒根間, 平均涇。

相對立セル，各齒根間ノ距離き測定 セルモノニシテ, 齒根先端部, 齒根 中央部測ル。

(1) 先端部。

2 根萊

3.4m.m.

3 根齒

近心根 $\longrightarrow$ 遠心頉側根 $4.7 \mathrm{~m} . \mathrm{m}$.

近心根↔遠心舌側根 $5.1 \mathrm{~m} . \mathrm{m}$.

遠心煩側根 $\rightarrow$ 遠心舌側根

7.2m.m.

(2) 中央部。

2 根齒

$2.7 \mathrm{~m} . \mathrm{m}$.

3 根苳

近心根 $\longleftrightarrow$ 遠心煩側根 $2.1 \mathrm{~m} . \mathrm{m}$.

近心根↔遠心舌側根 $1.8 \mathrm{~m} . \mathrm{m}$.

遠心煩側根 $\longrightarrow$ 遠心舌側根

$2.9 \mathrm{~m} . \mathrm{m}$.

2 根齒/齒根分岐部八 $0.4 \mathrm{~m} . \mathrm{m}$. = シテ, 3 根齒/遠心煩舌兩根/分岐 點八齒頸部 $\exists$ 平均 $3.2 \mathrm{~m} . \mathrm{m}$. /位 置ナリ。

齒根長徑二就イテハ諸學者間二種々 ナル交獻アリ。

G. V. Black. Mühlreiter.

平均 $13.2 \mathrm{~m} . \mathrm{m}$. 本均 $15.0 \mathrm{~m} . \mathrm{m}$.

最長 15.0 m.m. Broomel and

最小 $11.0 \mathrm{~m} . \mathrm{m}$. 本均 0.52 inch 
Choquet.

平均 $14.4 \mathrm{~m} . \mathrm{m}$.

河野, 廣瀨

本均 $11.2 \mathrm{~m} . \mathrm{m}$.

最 長 $12.9 \mathrm{~m} . \mathrm{m}$.

最小 $8.7 \mathrm{~m} . \mathrm{m}$.

Lenhossék

Distalwurzel $15.0 \mathrm{~m} . \mathrm{m}$.

Mesialwurzel $15.0 \mathrm{~m} . \mathrm{m}$.

宮 原

$11.6 \mathrm{~m} . \mathrm{m}$.

奥村, 渡櫋

$$
\begin{array}{cc}
\text { 本均 } & 11.6 \mathrm{~m} . \mathrm{m} . \\
\text { 最長 } & 14.2 \mathrm{~m} . \mathrm{m} . \\
\text { 最小 } & 8.8 \mathrm{~m} . \mathrm{m} .
\end{array}
$$

3 根齒八 5 本二 1 本ノ割合ニシテ，柴田氏ハ $14.6 \%$ 子報告セリ。

以上ハ齒根數及ビ俓數/本均數丹述べタルモノニシテ，次二形態學的二齒根丹分類 スレバ次ノ 5 種キ區別シ得。(1257瑶根)

(A) 圓錐型䔢根。

根先端，銳尖ニシテ所謂圓錐形キ呈スル齒根ニシテ，近遠心面扁平，縱溝著明ナル モノナリ。煩舌, 兩面, 豐隆圓澤ニシテ中央部陷凹ス。

$\begin{array}{lll}666 \text { 齒根 } & & 53.0 \% \\ \text { 近心根 } & 297 \text { 本 } & 23.6 \% \\ \text { 遠心根 } & 369 \text { 本 } & 29.4 \%\end{array}$

圓 錐 型 齒 根

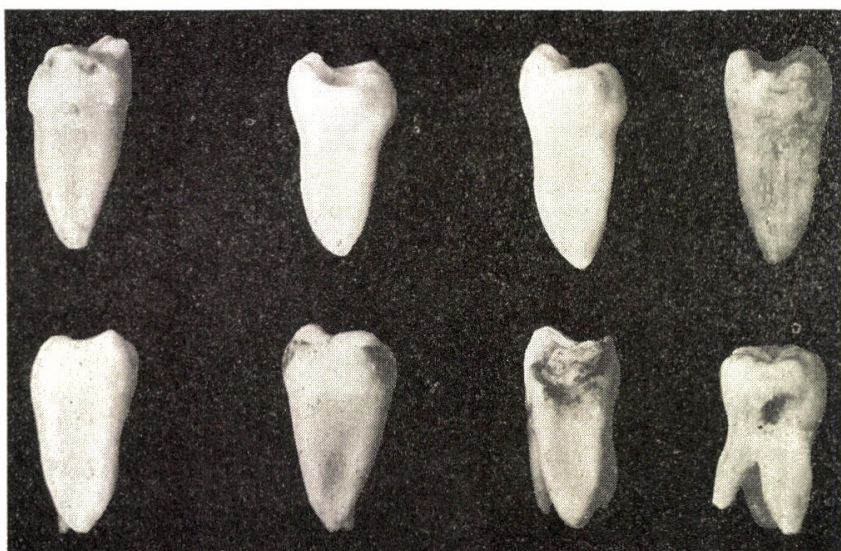

(A)

(B) 方型齒根。

多ク壓本分離セントスル齒根ニシルモノニシテ, 根先端 2 個 キ有シ, 齒頸部横徑卜 
根先端ノ横徑卜略了相等シキ, 師チ正方形樣ノ齒根ナリ。近遠心面中央部ハ著シク扁 本。縱溝最モ明カナリ。先端, 中央部八厴本二低りテ队部へ陷凹シ, 溝, 縱走卜相待 ッテ 2 根二分雄セントスル形狀タ呈ス。或ハ然ラズシテ， 2 根ガ漸次接近相癒合シテ 方 型城根
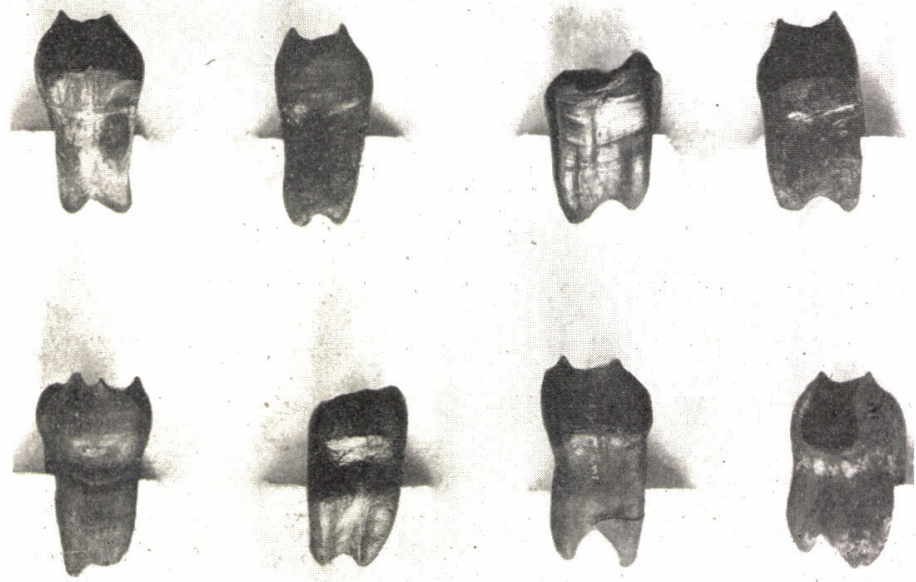

(B) 脫灰後撮影

1 根き形成七ントスルガ如キ傾向キ示シ, 縱溝キ界卜シテ, 縱斷スレバ, 各個ガ 1 根

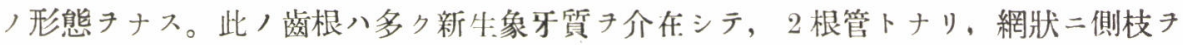
出シテ相連絡スルチ常トス。

267 齒根

近心根

遠心根
195齒根

72 齒根

圆 頭 型 蒛 根

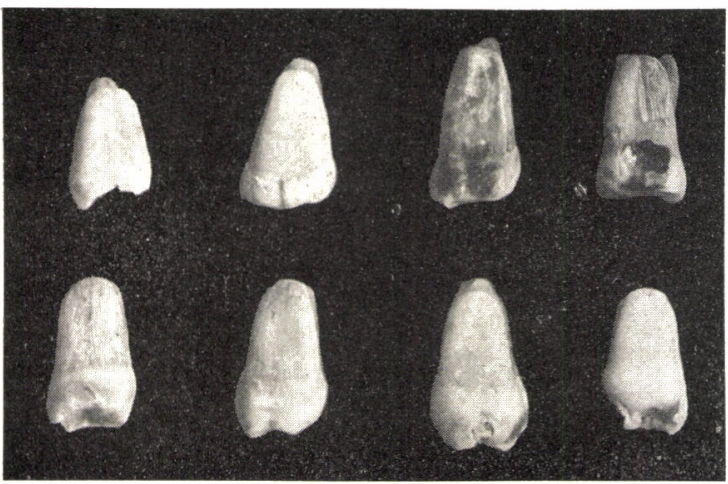

(C)
$21.2 \%$

$15.5 \%$

$5.7 \%$

(C) 圓頭型齒根。

之レハ根先端, 指頭狀二圓 形キ呈シ, 膨隆, 肥厚七几形 狀ナリ。縱溝不明ニシテ, 或 ルモ! 八不鮮明二, 或ルモ， 八痕跡, 氵 子殘シ, 又八全り 認メ得ザルモノモ有り。近遠 心面, 煩舌面, 互 $上$ 二膨隆 シ テ, 全齒根根棒狀キナス。斯 如キ齒根八遠心面彎曲度少》 
多ク八直立ス。一般二 1 根管丹通ズルモ, 時二八高位二於テ分岐タナシ, 根先端二於 テ再ビ相合スルモノモアリ。

$\begin{array}{lrr}\text { 180齒根 } & & 14.3 \% \\ \text { 近心根 } & 102 \text { 齒根 } & 8.1 \% \\ \text { 遠心根 } & 78 \text { 齒根 } & 6.2 \%\end{array}$

(D) 刀型齒根。

此, 形狀八煩舌側何レカ, 面が略々一直線キナシ, 其他面ガ圓キ描キ先端二於テ相

刀 型 蓄 根

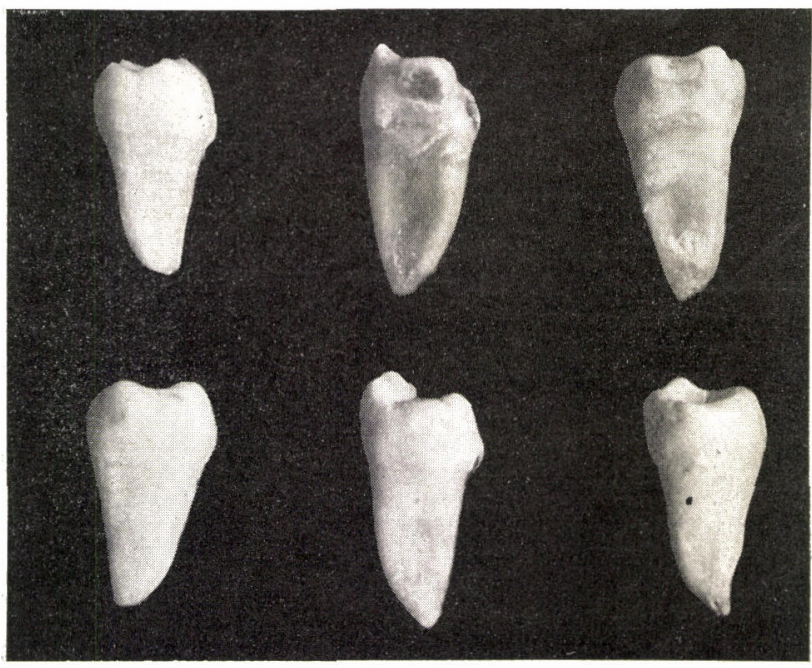

(D)

分離三根型齒根

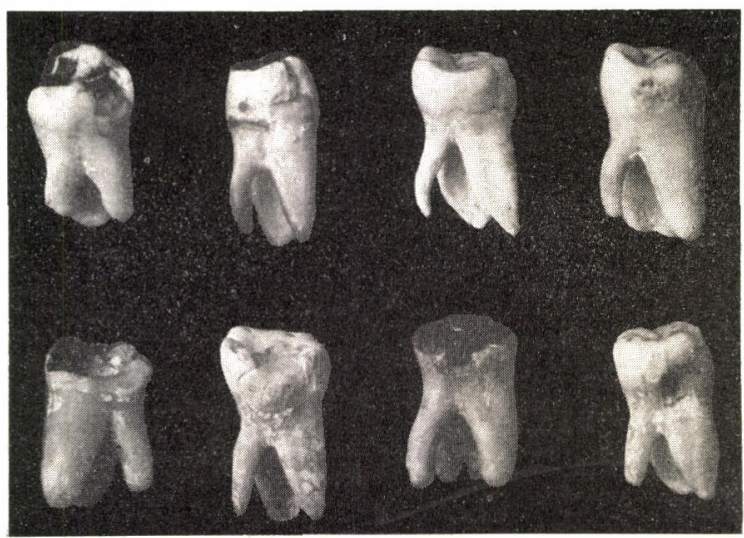

(E)
合スル型，郎刃物狀キナ セルモノナリ。而シテ刃 ，春二相當スル部八肥厚 シ，刃二相當スル部八菲 薄ナリ。一般二頓側面肥 厚シ, 舌側面菲薄ナリ。 縱溝八明カナルモ, 又近 遠心面稍 ? 豐隆シテ不明 暸ナルモノモアリ。又近 心根，遠心面，遠心根， 近心面八極端二明ラカナ ルモノモアリ。

\section{4苳根}

$11.5 \%$

近心根 42 齒根 $3.3 \%$

遠心根 102齒根 $8.2 \%$

(E) 分離 3 根型齒根。 形態學的分類ニ八非ザ ルモ, 異常齒根トシテ便 苴上此處二加入入。近心 根ハ多ク圓錐型齒根ナル モ, 方型, 圓頭型, 刀型 ノ各齒根型モ少カラズ。 遠心頓, 舌兩根八細小, 圓錐型齒根ノそナリ。 
齒牙 735 齔中

135 齒 $18.4 \%$

柴田信氏ノ齒根三角ニナラヒ, 該型ノ齒根先端部涉ビニ根間中央部ノ各部三點テ結 ビ圖ノ如キ三角形キ作レバ，根間距離相互關係キ推知シ得。

[圖解說] (1) / $\mathrm{A}$ 八各齔根間先端部/本均徑三角ニシテ, $\mathrm{B} 八 1$ 齒牙二於テ, 遠 心煩側根, 遠心舌側根, 兩根間ノ最長ナルモノ、三角キ示シ, 小線三角形八同歯ノ中 央部齒根間三角ナリ。郎チ同一齒牙ニ於ヶル中央部ト先端部トノ根間關係キ示七ルモ

\section{$(-)$}

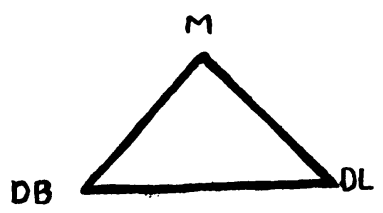

A
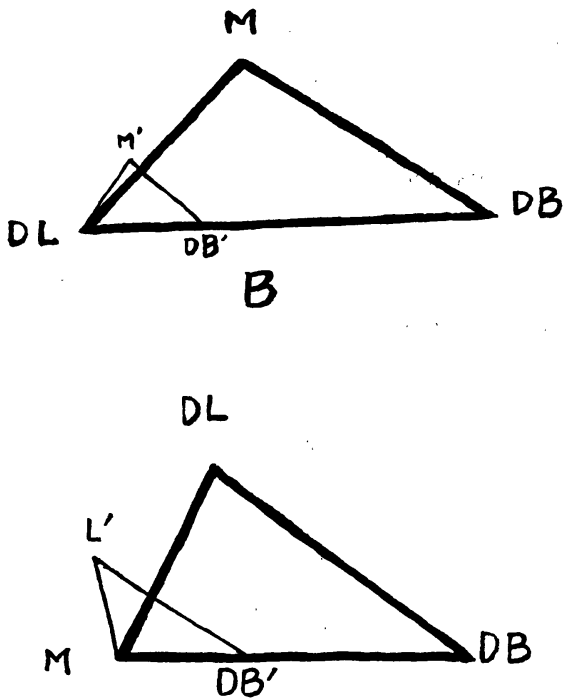

C

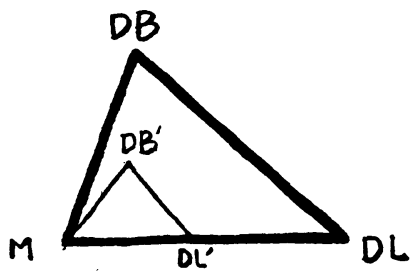

D

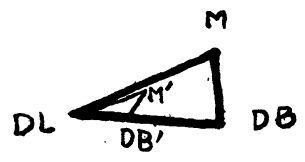

$E$

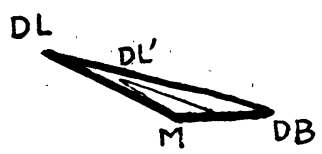

$F$

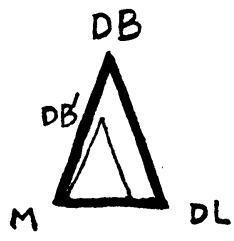

G 
ノナリ。 C 八近心根. 遠心頓側根間, D八近心根, 遠心舌側兩根間/最長三角ナリ。 $\mathrm{E}$ 八遠心煩側根，遠心舌側根々間ノ最短ナルモノ、三角ニシテ，小線ノ三角形八同齒 ノ中央部根間キ示ス。 $\mathrm{F}$ 八近心根, 遠心煩側根々間, $\mathrm{G}$ 八近心根, 遠心舌側根々間, 最短ナル三角ナリ。

（2）ノ $\mathrm{A}^{\prime}$ 八各齒根間中央部ノ平均三角ニシテ, $\mathrm{B}^{\prime}$ 八遠心煩側根, 遠心舌側根々 間中央部ノ最長ナル一齒牙二於ケル三角キ示シ，小線ノ三角形ハ同齒ノ先端部齒根間

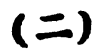

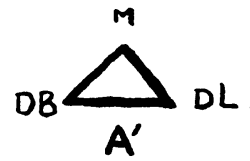
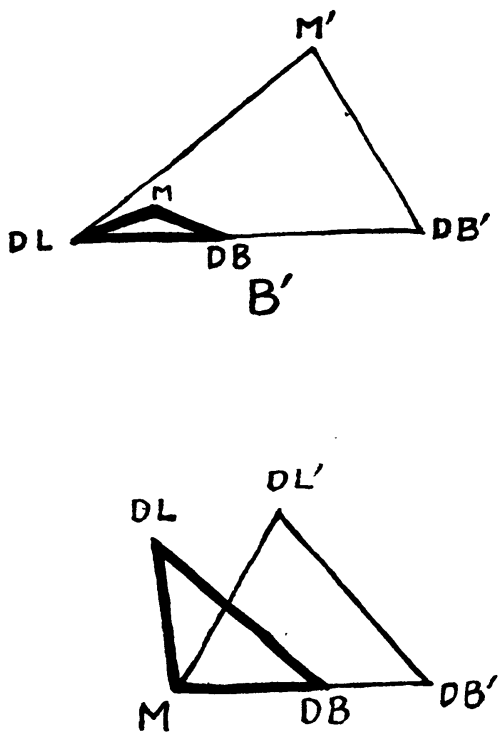

$C^{\prime}$
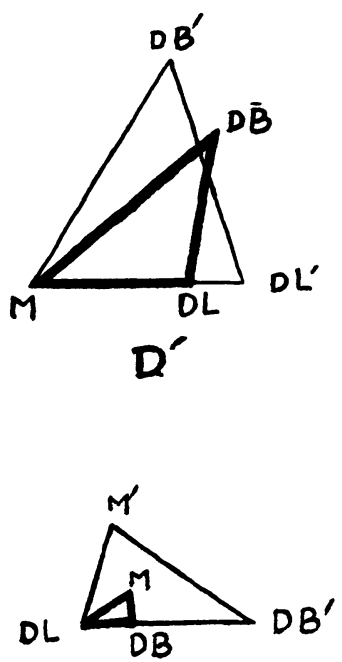

$E^{\prime}$

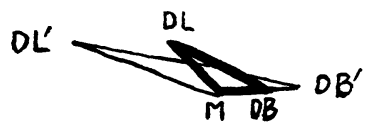

$F^{\prime}$

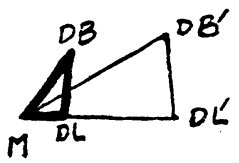

$G^{\prime}$ 
(E)

\begin{tabular}{|c|c|c|c|c|c|c|c|}
\hline & & 菌根 & 讧 徑 數 & (57菌根) & & & \\
\hline 蓖型 & 部 & 位 & 本 & 最 & 長 & 最 & 短 \\
\hline 圆 & 蒠 & 根 長 徑 & $11.5 \mathrm{~mm}$ & $18.8 \mathrm{I}$ & $\mathrm{mm}$ & $5.9 \mathrm{~mm}$ & \\
\hline 型 & & 蓠 頸 部 & 7.3 & 10.3 & ", & 2.9, & \\
\hline 根 & & 中 央 部 & $4.5 \quad$ & 9.7 & $"$ & $2.6 "$ & \\
\hline 方 & 苜 & 根 長 徑 & 14.3, & 15.7 & ," & 6.0, & \\
\hline 型 & & 图 頸 部 & $9.1 "$ & 11.5 & ," & $7.5 "$ & \\
\hline 苗 & & 中 央 部 & $8.2 "$ & 10.9 & $"$ & 5.3 & \\
\hline T2x & & 先 端 部 & $4.1 "$ & 8.5 & $"$ & $2.4 "$ & , \\
\hline 圓 & 齒 & 根 長 徑 & 13.9 & 16.5 & ", & 5.8, & \\
\hline $\begin{array}{l}\text { 型型 } \\
\text { 型离 }\end{array}$ & & 齿 頸 部 & 8.6, & 10.7 & $"$ & 7.2 & \\
\hline 根 & & 中 央 部 & 7.9, & 9.0 & " & $5.6 "$ & \\
\hline 刀 & & 根 長 徑 & 10.2, & 14.5 & ", & 7.5, & \\
\hline $\begin{array}{l}\text { 型 } \\
\text { 㐭 }\end{array}$ & 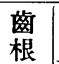 & 蓠 頸 部 & 8.8, & 10.0 & $"$ & 7.0, & , \\
\hline 根 & $\begin{array}{l}\text { 橫 } \\
\text { 徑 }\end{array}$ & 中 央 部 & $7.9 "$ & 9.0 & " & 6.3, & , \\
\hline
\end{tabular}

ナリ。以下 $\mathrm{C}^{\prime}-\mathrm{G}^{\prime}$ 八䐓次(一)

ノ $\mathrm{C}-\mathrm{G}$ 卜同ジ意味ノ三角二 シテ, 大線三角八中央部, 小 線三角ハ先端部キ示スモノナ リ。

\section{B 根 管}

從來齒根, 觀察八比較的等 閉二付セラレタル傾向アリ テ, 形態學的, 解剖學的研究 餘地ハ, 今劣ホ僅少ナラザル 二反シテ，其ノ內部二包括サ ル、根管, 觀察八, 前述, 如 キ戗多ノ學者二依リ普ク攻究 セラレタリ。其ノ研究方法, 業 績ハ衆知ノトコロナリ。

Zurcher 氏ノ根管分類。

(1) Zweige (2) Seitenfederchen (7) Äste ( 3 ) Dentin Scheidewande (4) Querbrückensysteme. (5) Inselartige Aussparungen (6) Apicale Verzweigungen (7) Markkanale

奧村氏ノ根管分類。

\section{（1）單純根管（2）分岐根管（3) 網狀根管}

以上 3 種ノ分類二更二次ノモノチ隨伴セリ。

（1）根管側枝 （2）管外側枝 （3）根端分岐。而シテ分岐根管二ハ,（a）高位分岐 (b) 低位分岐 $\left(a^{\prime}\right)$ 完全分岐 $\left(b^{\prime}\right)$ 不完全分岐。

以上 2 氏ノ分類ハ世人熟知ノモノナリ。余八微細ナル組織學的所見及ビ是等ノ分類 八省略シ唯ダ是等分類キ參考ニシテ數的二變更シタルモノキ觀察セリ。

一般二下顎第一大四齒, 根管八, 遠心二 1 個, 近心二頓舌的二各々 1 個 備フルモ， ニシテ, 略 了齒根ノ類及ビ其ノ形態ニ一致シテ存在スルモノナリ。然ルニ齒牙發育中 二於テ, 齒根或八根管內二於テ種々ナル数化ノ生ジル場合八, 正規ノ外觀キ有スル

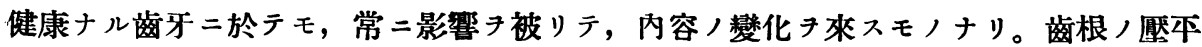


二因スル根管容積ノ縮小, 或八新生象牙質形成二依ル高度ノ變化等ノ諸現象二從七、 根管ノ形態, 數, 變化八生理的二發育完了七ル齒牙二於テ常二認ムルモうニシテ, 斯 如キ構造ノ變化八病的機轉ノモノニ非ザルナリ。

余ノ調查セル成績八前述ノ方法二從七テ製作シタル, 透明標本 444 齒二就イテ, 根 管口, 髓管, 側枝觀察セルモノナリ。

(A) 根管口。

根管口八概子, 根管ノ數及ビ位置二一致シテ, 遠心二 1 個, 近心二煩舌的二各 31 個ヨ有スルチ常トス。然乍，根管口モ亦，根管ノ變化ノ影響キ被リテ，正常ノ數及ビ 位置ヨ變ズル事夥シ。余ハ此ノ變化二起因スル根管口ノ位置及ビ數二就イテ, 次ノA 型, $\mathrm{B}$ 型, $\mathrm{C}$ 型, $\mathrm{D}$ 型止區別セリ。

(1) A 型。此ノ狀態ノモノ八, 正常ノ根管ロテ有スルモノニシテ, 骨遀牀底ノ近心部 二各 3 1 個丹有シ, 遠心部二 1 個キ有スルモノナリ。遠心部ノ根管口ノ形態八, 扁本

\section{A 型}

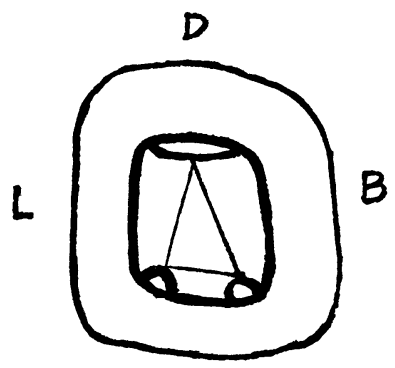

$M$

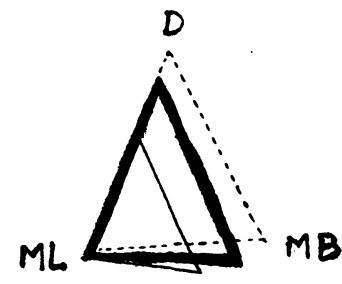

大線三面川平坞距襍

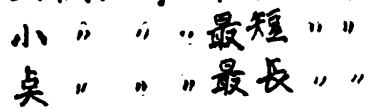

ナル楉圓形キ呈シ，最モ大ナリ。近心舌側根々管口之二次ギ，圓形二近キ小陼圓形キ ナス。頓側根々管ロハ殆ンド圓形キナス。

平均數 273 齒 $61.5 \%$

各根管口間ノ距離。

遠心根管口 $\longleftrightarrow$ 近心頓側根管口。

本均距離 $3.9 \mathrm{~m} . \mathrm{m}$.

最長 . $\quad 4.3 \mathrm{~m} . \mathrm{m}$.

最短 " $2.8 \mathrm{~m} . \mathrm{m}$. 
遠心根管口な近心舌側根管口。

$\begin{array}{ll}\text { 本均距離 } & 3.9 \mathrm{~m} . \mathrm{m} . \\ \text { 最長 " } & 4.3, \\ \text { 最短 " } & 3.3,\end{array}$

近心煩側根管口な-近心舌側根管口。

\begin{tabular}{|c|c|}
\hline 平均距離 & $2.9 \mathrm{~m} . \mathrm{m}$ \\
\hline 最長 " & $3.6 "$ \\
\hline 短 & $2.0 "$ \\
\hline
\end{tabular}

$\mathrm{A}$ 型ノ齒根及ビ根管ト, 關係。個々ノ齒牙二就イテ觀察スルニ 2 根苳ニシテ, 近遠 心兩根共二, 圓錐型齒根最モ多キモ, 刀型、圓頭型, 各齒根亦少カラズ。根管ハ 3 個 ノ根管口ヨリ, 是等齒根ノ形二一致シテ經過スルモノニシテ, 分岐, 側枝等ノ構成少 ク，比較的單純ニ終ルモノナリ。

（2） B型。髓牀底二於テ近心, 遠心各部中央二各? 1 個ノ根管口チ有スルモノ= シテ, 大サ兩ロトモ殆ンド同ジク, 大サ, 形ハ A型ノ遠心根管口二類似スルモ, 稀二
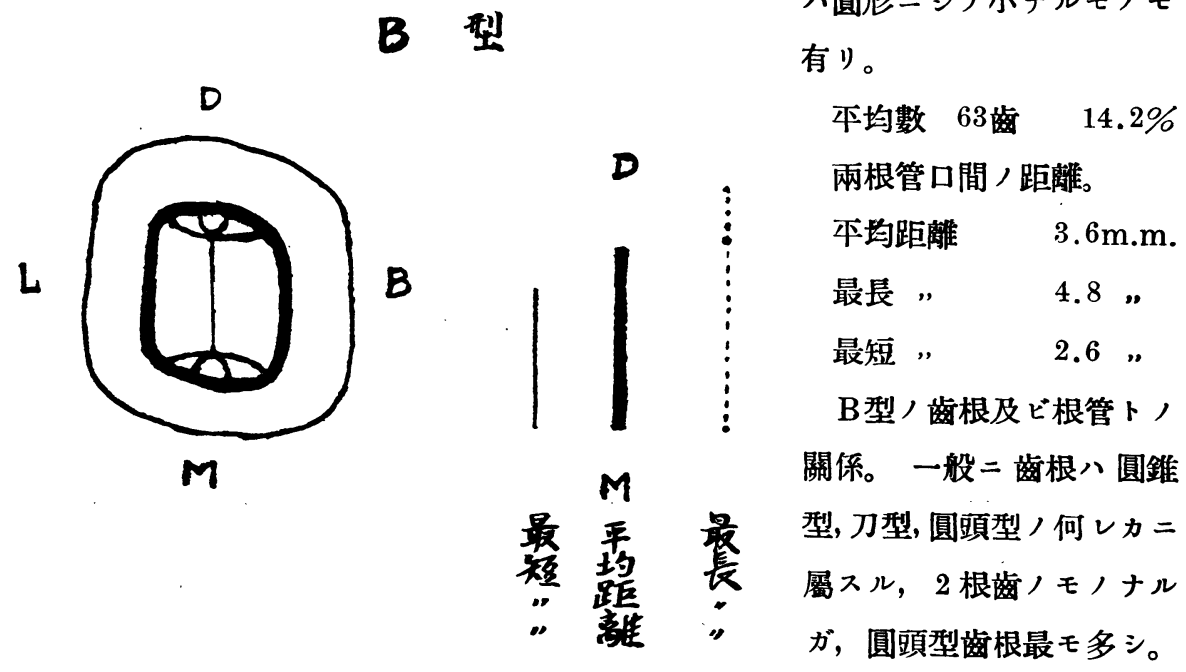
八圓形ニシテ小ナルモノモ 有り。

本均數 63 苳 $14.2 \%$ 兩根管口間ノ距離。

$\begin{array}{ll}\text { 最長 }, & 4.8 ” \\ \text { 最短 } & 2.6 ”\end{array}$
關係。一般二齒根八圓錐 型, 刀型, 圓頭型ノ何レカニ 屬スル， 2 根齒ノモノナル ガ, 圓頭型齒根最モ多シ。

近心根八正規ノモノ 二比シテ一般二小ナリ。遠心根管ハ單純根管キナスモ, 近心根管 八比較的複雜ナル變化テナシ，根管內部二於テ分岐シ，2根管トナレルモノアリ。郎 チ根管口數ト根管數トハー致セザルモノナリ。斯ル根管ニ於テハ，管外或ハ根端側枝 ハ少數ナルモ，管間側枝き出シテ相連絡スルモノ多シ。

（3） C 型。此, 型八髓牀底/近心部, 遠心部/各隅角二近っ併列スル4個/根管 
ロヨ有スル齒牙ナリ。4 個共ニ甚ダホニシテ, 圓形キ呈シ，A型ノ近心舌側根管ロト 稍 3 類似ス。

C 型

D

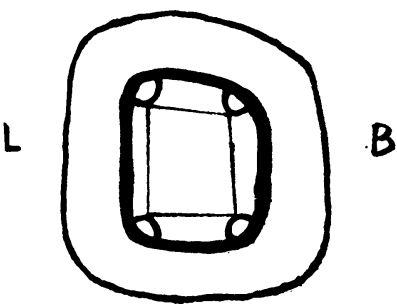

M

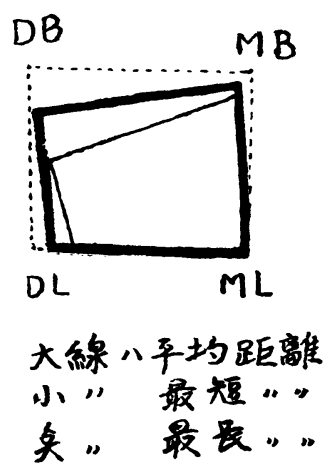

本均數 84齒

$18.9 \%$

各根管口間ノ距雄。

遠心舌側根管口 $\longleftrightarrow$ 遠心煩側根管口。

本均距雄

$2.6 \mathrm{~m} . \mathrm{m}$.

最長，

3.6 ,

最短.,

1.8 ,

遠心舌側根管口 $\rightarrow$ 近心舌側根管口。

本均距䧺 $3.8 \mathrm{~m} . \mathrm{m}$.

最長 , 4.3 ，

最短 , 3.3 ,

遠心煩側根管口 $\longleftrightarrow$ 近心煩側根管口。

本均距離 $4.1 \mathrm{~m} . \mathrm{m}$.

最長 , , 4.4 ,

最短, , 3.9 ,

近心舌側根管口近心煩側根管口。

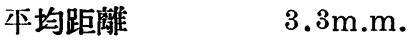

最長 , $\quad 3.5$,

最短, 3.0 , 


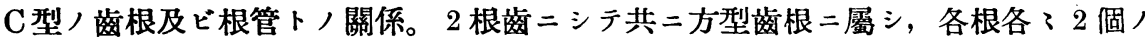

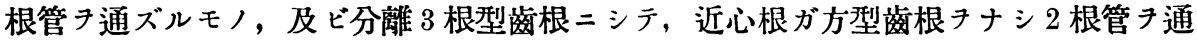
ジテ，遠心根ト 4 根管き構成スルモノナリ。此ノ 4 根管ノ幹部八單純二全長 經過ス ルモノ多キモ，亦或ルモノ八，2根管口キ經テ内部二至ルヤ相合シテ太キ 1 根管二變 化スルモノアリ。或八又相合シタルモノガ再ビ分離シテ根端二至ルモノアリ。而シテ 同一齿根內ノ兩根管八，互ヒ二數多ノ管間側枝キ出シテ網狀二連絡ス。管外側枝モ亦 少カラズ。

（4） D型。此ノ型ハ $\mathrm{A}$ 型ノ逆ニシテ，遠心部二頓舌的ノ 2 個 キ有シ，近心部 $=1$ 個 有スル齒牙ナリ。其ノ個々ノ形狀及ビ大サモ略 了 $\mathrm{A}$ 型二等シ。

\section{D 型}

$D$

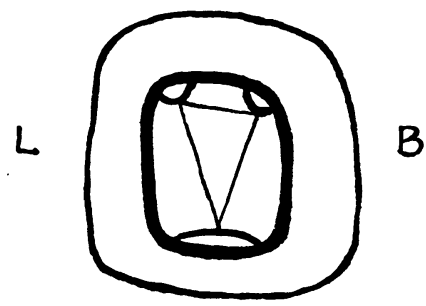

M

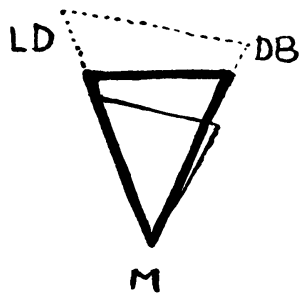

A型，説明卜全啴

本均數 24齒

$5.4 \%$

各根管口間, 距離。

遠心頓側根管口↔遠心舌側根管 [。

本均距雄 $3.3 \mathrm{~m} . \mathrm{m}$.

最長 ,, 3.8 ,

最短, 2.7 ,

遠心頓側根管口↔近心根管口

$\begin{array}{ll}\text { 本均距雕 } & 3.6,, \\ \text { 最長 ., } & 4.4,, \\ \text { 最短 , } & 2.8,,\end{array}$

遠心舌側根管口 $\leftrightarrow$ 近心根管口

本均距雄

4.1m.m. 
$\begin{array}{ll}\text { 最長 , } & 5.0, \\ \text { 最短 , } & 3.5,\end{array}$

D型/齒根及ビ根管卜，關係。此/モノ、齒根ハ總テ，分㕍三根型齒根ニシテ，4
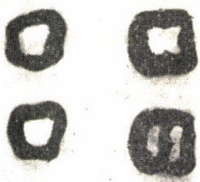

(1) 21

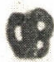

요

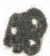

$0 \%$

80

10

$0^{\circ}$

14.

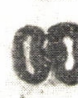

68

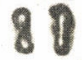

80

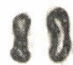

88

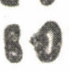

10
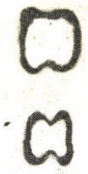

a

(2)

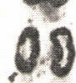

00 \&8

08

81

18

(8)

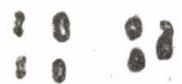

(2)

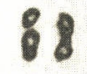

i8

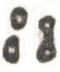

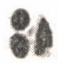

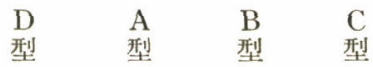
型中奇型 呈シ, 近心根管口ハB型近心根管口 ノ如ク 1 個キナシ，根管モ亦近心二於テハ 1 個 キ通ジ, 遠心二於テ八分離シタル各根中二各々 1 個尹通ズ。近心根二於テハ 1 根管ロヨリ發シ タル根管ガ内部二於テ 2 根管二分岐シ，又一度 分岐シタルモノが根端二於テ再ビ相合スル事モ アリ。又稀二遠心根, 方型齒根ニシテ 1 根チナ シ, 内部 $=2$ 根管キ有シテ, 近心根, 1 根管卜 3 根管口 3 根管 構成スルモノアリ。

(B) 髓管 (根管)

Zurcher 氏, 奥村氏，根管分類于參考ニシテ， 數的二變更シ，余心次，如キ比， 1 根管卜ナ 七リ。終始 1 根管二テ經過七ルモ,，及ビ根管 ロハ 1 個ナルモ，根管內高位二於テ新生象牙質 7 介在シテ分離シ, 直二再ビ相合シテ 1 根管卜 ナリ根端二至ルモノ，及ビ根管口 2 個ナルモ, 根管内高位二於テ相合シテ根端孔マデ 1 根管 ナセルモノ, 或八低位二於テ小ナル圓キ成シテ分雄シ, 再ビ合シテ終ルモ,ナリ。次 ニ 2 根管ナルモノ八, 初メヨリ 2 根管二終始スルモ, , 或八根管口 1 個ナルモ根管內 高位二於テ分岐シ，相會スル事ナク根㸣孔二終ルモ，及ビ根管口 2 個ニシテ，根端 孔近クニ於テ相會シテ終ルモ,等ナリ。

以上ノ意義ヨリシテ根管調査成績习述ブレバ,
(1) 2 根管, 齒牙
173 齒
$39.2 \%$
（2） 3 根管，齒牙
183 齒
$41.2 \%$

(a) 近心根 遠心根 1$\}$ 齒牙 141 齒 $31.8 \%$

(b) 近心根 遠心根

${ }_{2}^{1}$ \}, 齒牙 42 齒 
（3） 4 根管, 齒牙

87 齒

$19.6 \%$

是等丹 1 齒根中二於ケル根管, 數キ近心及ビ遠心兩根二就イテ述ブレバ,

(1) 1 根管

（a）單純ナル， 1 根管站ビ $=2$ 根管

(a) 近心根 $31.8 \%$
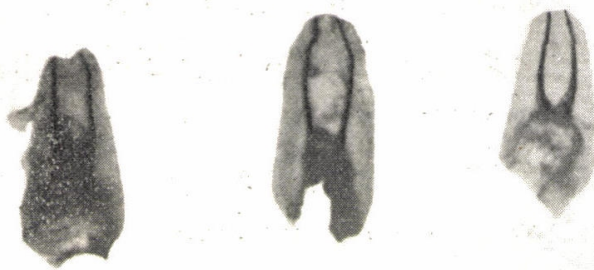

（b）遠心根 $68.7 \%$
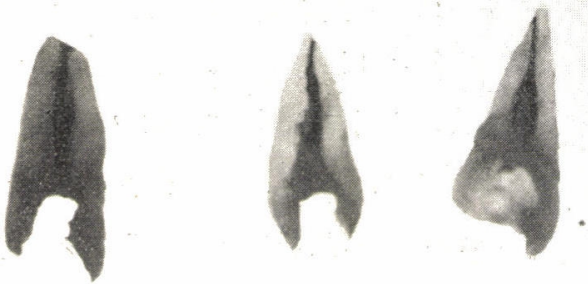

（b）低位，高位，分岐狀態
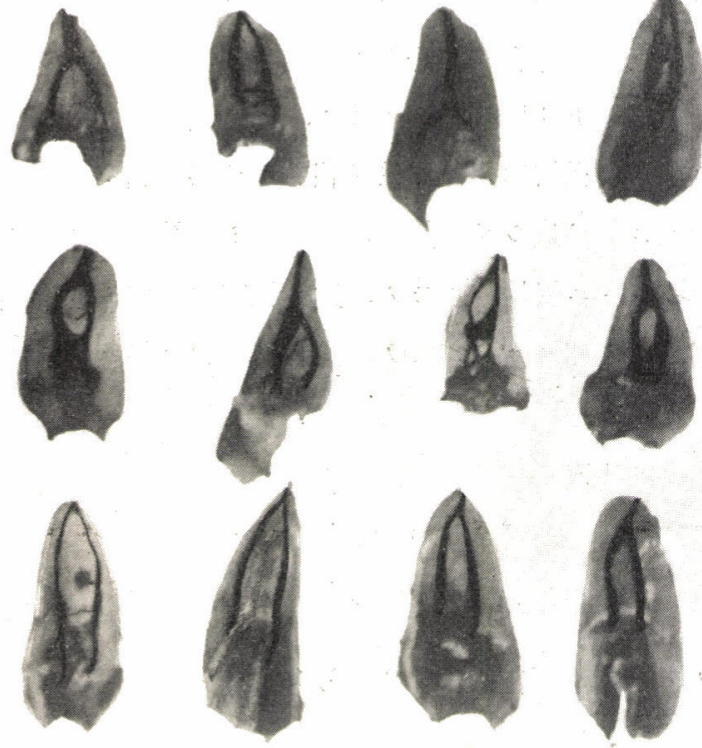
$4.7 \%$
(a) 近心根
42 齒

\section{（2） 2 根管}

(a) 近心根 $73.8 \%$

（b）遠心根 $26.2 \%$

以上, 本均數八, 前述 , 如々分岐程度学數的 $=$ 觀察シタルキ以ッテ, 諸 學者, 發表七ル成績卜八 相當懸隔又。約 3000 個， 芷牙二就イテ根管數习調 查シタル Hess 氏二依レ 心゙, 該苳ノ根管數八, 2 根管18\%，3 根管80\%， 4 根管 $2 \%$ 子報告セり。

(C) 側枝。

網狀根管キナス側枝み 管間側枝二加入シテ, 管 外側枝, 根崩倒枝, 三ッ 二就イテ, 記載スレバ, 3 側枝/合計 246 齒 27.7 $\%$ シテ, 近心根 177 齒 $23.3 \%$ ，遠心根 69 齒 7.8 \%アリ。是等于各側枝別 ニ述ブレバ次, 如シ。

（1）管外側枝。 66 齒.... $7.4 \%$ 
（c）側枝，分布狀態
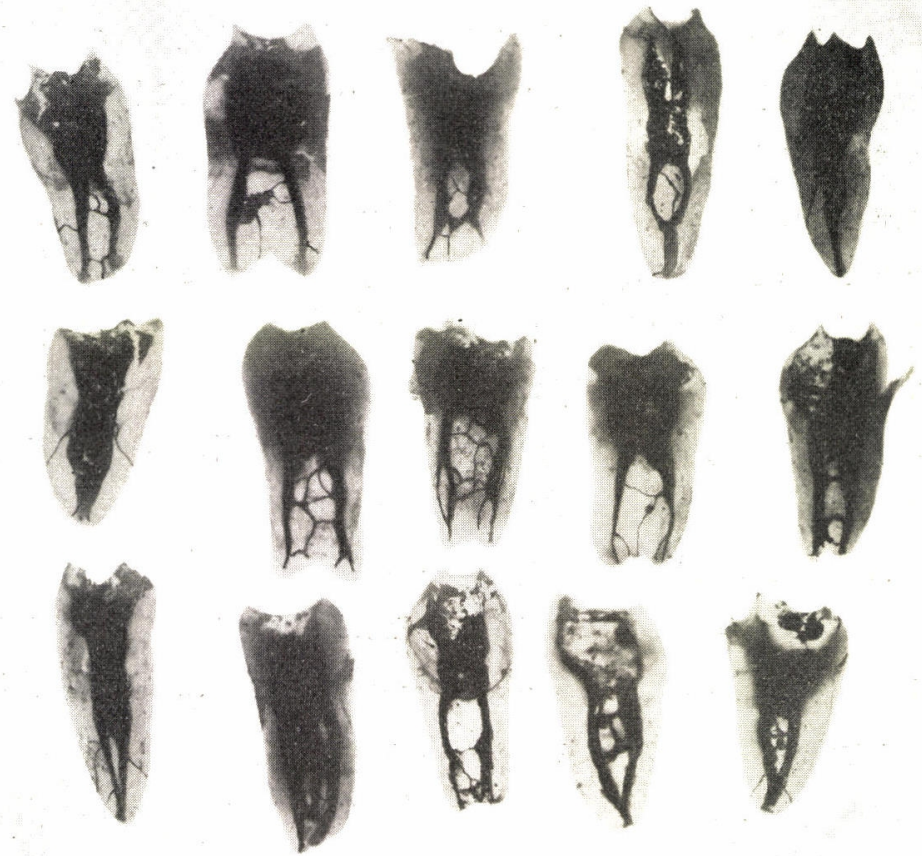

(b) 遠心根

24 莢

$2.7 \%$

(2) 管間側枝

150 揭

$16.9 \%$

(a) 近心根

120 齒

$13.5 \%$

(b) 逶心根

30 唡

$3.4 \%$

(3) 根踹側枝

30 齒

$3.4 \%$

(a) 近心根

15 齿

$1.7 \%$

(b) 遠心根

15 齒

$1.7 \%$

Hess 氏八側枝 $13.5 \%$, 根端分岐 $7.3 \%$ 報告セり。

\section{考察結論}

以上記載七ル成績ヨリ觀察スルニ,

(1) 該齒牙)齒根數八約 $8: 2$ ノ比二シテ 2 根葍多ク, 成書二示入ガ如ク大體二於

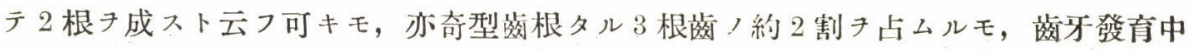
及ビ完了後, 變化二少カラ又關係丹含ムモノナリ。 
(2) 齒根/長サ二於テ. 近遠心兩根キ比较スレバ, 常二近心根長ク平均 $1.1 \mathrm{~m} . \mathrm{m}$.横 徑/起始部二於テ $0.5 \mathrm{~m} . \mathrm{m}$. 中央部二於テモ $0.5 \mathrm{~m} . \mathrm{m}$. /長キ本均チ有シ，分蜼 3 根齒 ニ於テモ一層長大キ示ス。之八遠心根ヨリモ, 近心根, 發有旺盛ナルが故ナリ。而シ テ分離 3 根齿, 近心根最モ長ク, 且ツ大ナリ。次ハ 2 根落/近心根ニシテ, 最モ短, 且.ツナルモノ八遠心舌側根ナリ。

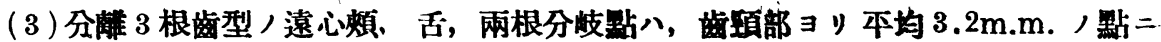
於テ分離スルモノニシテ，近遠心兩根，如ク完全二分㒕スルモノハ少シ。

(4) 齒根ノ形態八圆錐型最モ多シト踓ドモ, 十分ナル觀察き行へバ, 種々雜多ノ形 態子具フルモノニシテ，便宜上區別セル余４ 4 型二止マラザル可シ。正規ノ形狀トシ テ，成書ニ示サレタル圓錐型齔根二對シテ，他型／平均合計約其／牛數き占ムルハ, 其ノ一證ナリ。

（5）根管口，4 型丹區別スルニ至リタルハ，齒根及ビ根管ノ變化き高度二被レル結 果二他ナラズ。然レドモ，內部及ビ外部ョリノ變化ト同一/秒化ヨ行フモノト，然ラ ザルモノトアルハ, 前述ノ成績ノ示ストコロニシテ, 踟牀時注意ス可キ事ナリ。郎チ (1) 齒根及ビ根管構造ノ變化二伴ヒ, 漸次根管ロニ於テモ, 同一/戀化 來シ, 其數

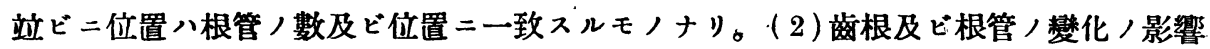
キ受ケテ, 變化ヨ行フモ, 異形ノ變化キナスモノフリ。(3)根管及ビ齒根二變化起リ タルモ，根管口ノ數及ビ位置二變化ナキモノアリ。

（6）根管數モ亦諸學者，論述セル如ク，單純ナル 3 根管二非ズシテ，4根管乃至八 2 根管 構成スルモノナリ。是等ノ數ノ變化八該齔ノ進化乃至八退化ノ一現象卜モ云 七得可三。

（7）側枝八微細ナル根管ニシテ，拔䯠時及ビ其ノ後處置,困難ハ㓜論, 如何ナル巧 妙ナル根管處置丹施シテモ，側枝ノ末端二迄到達スル處置八不可能ナル可シ。余ノ肉 眼上ノ調查二於テハ, $27.7 \%$ 算スルモ，顯微鏡下二於テえレチ述ブレバ，警ク可キ 數き發見シ得可シ。(了)

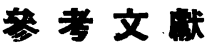

1) Die Pulpaamputation (Preiswerk. Öst. Ung. v. F. Z. 1901). 2) Über Pulpenausgüsse (Moral. D. M. F. Z. 1914. 8). 3) Über die feinere Anatomie der Wurzelkanäle menschlicher Zähne. (Fischer. M. F. Z. 1907. Sep.). 4) Zur Anatomie der Wurzelkanäle des menschlichen Gebisses mit Berücksichtigung der feinern Verzweigung am Foramen apicale (Hess. Schweiz. V. F. Z. Nr. 1. 1917). 5) Zur Anatomie der Wurzelkanäle des menschlichen Milchgebisses und der 6 Jahr-Molaren. (Zürcher, Schweiz. M. F. Z. H. 9. 1922). 


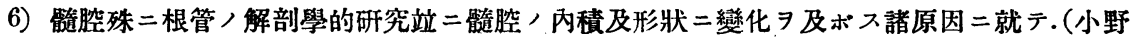
寅之助. 蓄科學報. 第 22 卷. 第 4 號). 7) 根管問題 =關スル第 2 報告. (奥村鶴吉. 梱科學報.

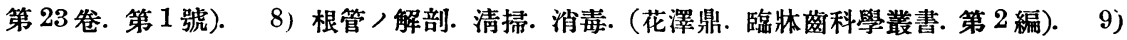
The Biology of Mulicanaliculated Roots (Grove. Dental Cosmos. 1916). 10) Über das Durchsichtigmachen von Zähnen und unsere Wurzelfüllungsmethoden. (Adloff. D. M. F. Z. 1913. H. 6). 11) 透明標本製作時, 順序及ビ方法. (八木氏啚科新報. 7 卷. 5 號. 12)

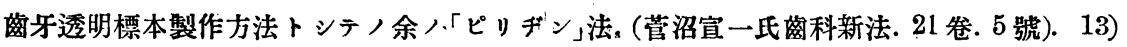

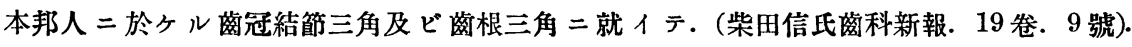
14) Makroskopische Anatomie der Zähne. (Lenhossék. Scheff's Handbuch der Zahnheilkunde. 1. Bd. 4. Aufl. Wien. 1922). 15) Die Wurzelkanäle der unteren Molaren und oberen zweiten Zahnheilkunde. (Port. 1915. 7). 